\title{
Congenital triangular alopecia
}

\author{
Francesco Lacarrubba, Giuseppe Micali
}

Department of Dermatology, University of Catania, Catania, Italy

\section{Correspondence to}

Professor Francesco Lacarrubba, francesco. lacarrubba@unict.it

\section{(1)-}

To cite: Lacarrubba F, Micali G. BMJ Case Rep Published online: [please include Day Month Year] doi:10.1136/bcr-2013202918

\section{DESCRIPTION}

A 4-year-old Caucasian girl presented with a 1-year history of asymptomatic, localised alopecia. Examination revealed a $3.5 \times 3.0 \mathrm{~cm}$ area of alopecia over the right frontotemporal region of the scalp, with its apex towards the vertex (figure 1). There was no scaling or erythema. Her father had a history of extensive androgenetic alopecia. Dermatoscopy of the scalp showed the presence of a 'carpet' of vellus hair over the area of interest (figure 2).

The girl suffered from congenital triangular alopecia, also known as temporal triangular alopecia, a circumscribed, non-cicatricial form of alopecia of unknown aetiology. ${ }^{1}$ It is clinically characterised by a triangular area, confined to one or both frontotemporal regions, in which there is an exclusive presence of vellus hair. It is usually observed in children between 2 and 4 years of age, during the time period in which the remaining scalp demonstrates replacement of vellus hair with terminal hair. Dermatoscopy serves as a useful tool to enhance the diagnostic capability, highlighting the clinical presence of vellus hair ${ }^{2}$ and allowing differential diagnosis with alopecia areata (showing the presence of dystrophic hairs) and scarring alopecia (showing the absence of hairs and follicles). ${ }^{3}$ This condition is viewed as permanent with no specific treatment.

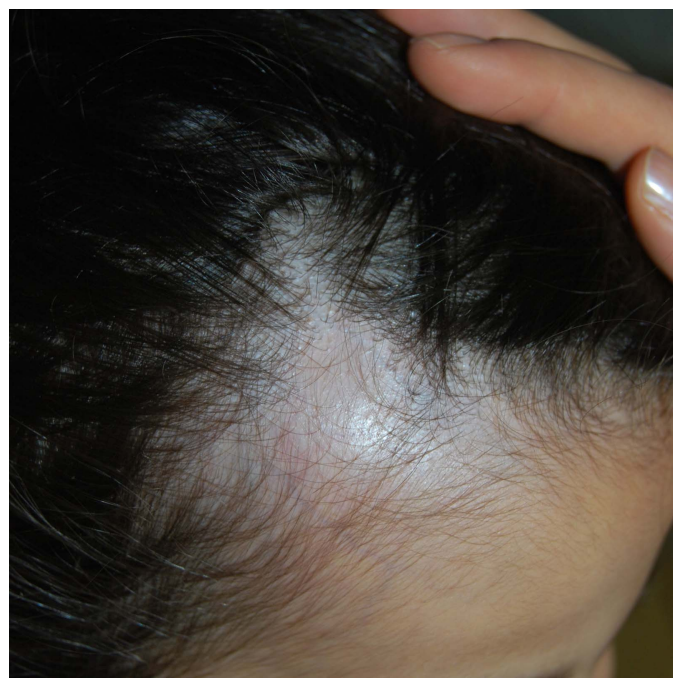

Figure 1 Area of alopecia over the right frontotemporal region of the scalp.

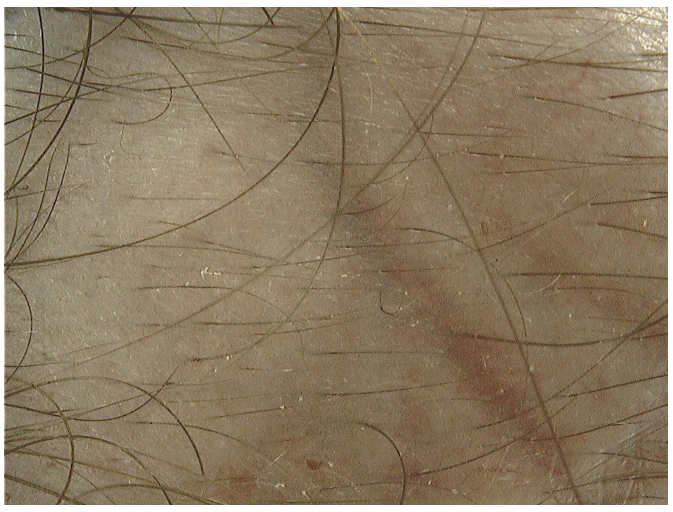

Figure 2 Dermatoscopy of the scalp showing the presence of a 'carpet' of vellus hair over the area of interest.

\section{Learning points}

- Congenital triangular alopecia is a circumscribed, non-cicatricial form of alopecia of unknown aetiology, usually observed in children between 2 and 4 years of age.

- It is clinically characterised by a triangular area, confined to one or both frontotemporal regions, in which there is an exclusive presence of vellus hair.

- Dermatoscopy serves as a useful tool to enhance the diagnostic capability, highlighting the clinical presence of vellus hair.

Contributors All authors had access to the data and a role in writing the manuscript, and approved the submitted version.

Competing interests None.

Patient consent Obtained.

Provenance and peer review Not commissioned; externally peer reviewed.

\section{REFERENCES}

1 Gupta LK, Khare A, Garg A, et al. Congenital triangular alopecia: a close mimicker of alopecia areata. Int J Trichol 2011:3:40-1.

2 Iorizzo M, Pazzaglia M, Starace $M$, et al. Videodermoscopy: a useful tool for diagnosing congenital triangular alopecia. Pediatr Dermatol 2008;25:652-4

3 Lacarrubba F, Dall'Oglio F, Nasca MR, et al. Videodermatoscopy enhances the diagnostic capability in some forms of hair loss. Am J Clin Dermatol 2004;5:205-8. 
Copyright 2014 BMJ Publishing Group. All rights reserved. For permission to reuse any of this content visit http://group.bmj.com/group/rights-licensing/permissions.

BMJ Case Report Fellows may re-use this article for personal use and teaching without any further permission.

Become a Fellow of BMJ Case Reports today and you can:

- Submit as many cases as you like

- Enjoy fast sympathetic peer review and rapid publication of accepted articles

- Access all the published articles

- Re-use any of the published material for personal use and teaching without further permission

For information on Institutional Fellowships contact consortiasales@bmjgroup.com

Visit casereports.bmj.com for more articles like this and to become a Fellow 